\title{
Analysis of Vulnerability in Emergency Situations in Kindergarten and Primary School Education Centers in Peru
}

\author{
Witman Alvarado-Díaz ${ }^{1}$, Alva Mantari Alicia² \\ Meneses-Claudio Brian ${ }^{3}$ \\ Image Processing Research Laboratory (INTI-Lab) \\ Universidad de Ciencias y Humanidades (UCH), Lima, Peru
}

\author{
Avid Roman-Gonzalez ${ }^{4}$ \\ Image Processing Research Laboratory (INTI-Lab) \\ Universidad de Ciencias y Humanidades \\ Lima, Peru
}

\begin{abstract}
The people who require greater protection and safety are children, mainly when they are in an educational center, where teachers are responsible for their care, therefore, it is important to have prepared teachers to face emergency situations, since, the sense of insecurity is greater in national schools due to the shortage of prepared teachers to handle emergencies situations in Peru; there are studies which mention that $98.2 \%$ of accidents in educational centers are trauma and falls, also 1 of every 4 students suffers a fracture, therefore, in this study, spatial data of kindergarten and primary education is presented from Peru, relating the number of students per teacher for the year 2019. The regions whose student-teacher relationship is risky for the welfare of the students are presented and analyzed by georeference, this data is public and is provided by the Ministerio de Educación de Perú (MINEDU), and using tools from the Geographic Information System (GIS), and it was possible to generate maps at the district level. Observing at the maps, it was possible to identify that the areas with the greatest risk are in the natural region of the jungle. Base on the spatial distribution of vulnerable points and outliers of the studentteacher relationship at the levels of kindergarten and primary education, it is recommended that governmental and nongovernmental institutions in Peru allocate resources urgently to reduce student vulnerability, reducing the relationship between the number of students and teachers, in order to get better the response to any accident or natural disaster.
\end{abstract}

Keywords-Geographic information systems; student-teacher relationship; students; teachers; maps; number of vulnerable students

\section{INTRODUCTION}

In 2015, at the General Assembly of the United Nations (UN) the member countries agreed on 17 Sustainable Development Goals (SDGs) for a better future. Goal number 4 is to ensure inclusive and equitable quality education and promote lifelong learning opportunities for all. One of its objectives is: by 2030 , substantially increase the supply of qualified teachers, including through international cooperation for teacher training in developing countries, especially least developed countries and small island developing states [1]. It must be in mind that the number of students is important to guarantee learning as well as to guarantee their safety in emergencies [2].
There are studies that mentioned that, one in four schoolchildren injured in schools suffered a fracture, dislocation or trauma from blows or falls that in most cases suffered in the classroom or during their studies hours of school [3].

Some data shown in [4] mention that it was observed that $98.2 \%$ of the cases were mainly direct injuries and falls, as well as fractures (15\%) and injuries (12\%).

In the research [5] they mention that generally all the teachers that participate in a training, related to first aid, these increase their knowledge, which can be applied in the students that suffer accidents.

The Ministerio de Educacion del Perú (MINEDU) through Ministerial Resolution No. 721-2018-MINEDU [6] has established that the maximum number of students per classroom is 20 for public educational institutions of regular basic education, therefore, in this study, all educational centers that do not follow the provisions of the MINEDU will be considered vulnerable, so schools with more than 20 students per classroom will be considered vulnerable.

In the research [7], carried out in the town of Chachapoyas-Peru, a study was conducted on the level of knowledge that teachers have in first aid, observing that $82.7 \%$ have a medium level of knowledge, $10 \%$ low knowledge, while that only $7.3 \%$ of teachers have high knowledge; which indicates that in an accident, the teachers would act poorly, due to only teachers with high knowledge could act in the right way.

A Geographic Information System is a set of tools that integrates and relates various components that allow storing, manipulating, analyzing and modeling data linked to a spatial reference, helping the incorporation of socio-cultural, economic and environmental aspects that lead to effective taking of decisions [8].

This work is structured as follows: In Section II, the research materials and methods used for the preparation of this work are presented. In Section III, it will know the descriptive results obtained from the observation of the corresponding maps. In Section IV, it will find the discussions, where we will try to compare with existing jobs. In Section V, there are the respective conclusions for this research. 


\section{MATERIAL AND METHODS}

The processing of the data has 3 stages shown in Fig. 1: Data acquisition, application of filters, and the creation of maps.

\section{A. Data Acquisition}

The public data corresponding to the educational centers and number of students and teachers, for 2019 were provided by the Ministerio de Educación del Perú (MINEDU). The maps of Peru are available in database (GADM, https: //gadm.org/download_country_v3.html) with its 25 regions and their corresponding districts.

The MINEDU data is provided in an Excel file, on which the filters are applied, to then save the data in "CSV" format, which it imports into the QGIS software version 3.8.0.

\section{B. Filter Application}

It should be taken into account that there are data that are irrelevant for processing, such as the records of national educational centers where there are no students or teachers, or where there are teachers and non-students or, on the contrary, schools where students and non-teachers are registered.

First, it finds the relationship between the number of students and teachers with equation 1.

$T=\frac{P}{D}$

Where: "T" represents the number of students per teacher. "P" represents the total number of students in the school. "D" represents the total number of teachers who teach at the school.

Then, it deletes all irrelevant data, and then separates the corresponding database for kindergarten and primary schools.

The analysis is carried out at the district level, analyzing the total number of students at risk, as well as calculating the student-teacher relationship by district, which allows to see the number of vulnerable students in the district.

\section{Map Creation}

Before creation, it should be taken into account that, in order to color vulnerable areas, it is enough that there is a school whose student-teacher ratio is greater than 20, which represents the existence of vulnerable students in emergency situations; In addition, in Table I, the reader can see general data of the student population nationwide.

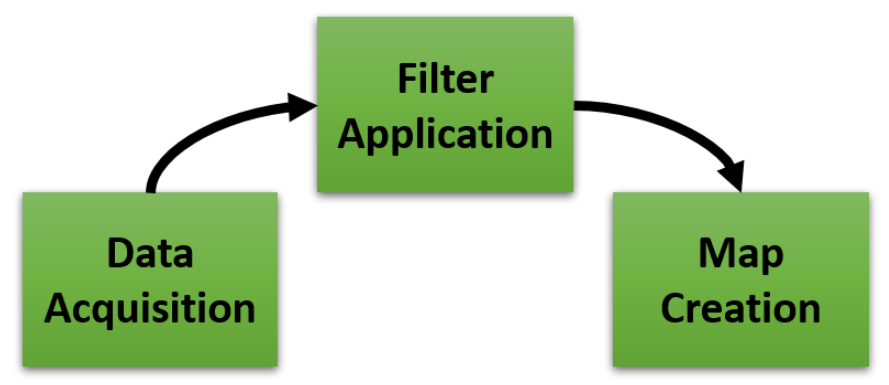

Fig. 1. Scheme of the Methodology to follow.
TABLE I. GENERAL DATA

\begin{tabular}{|l|l|l|}
\hline & $\begin{array}{l}\text { Kindergarten } \\
\text { Educational } \\
\text { Center }\end{array}$ & $\begin{array}{l}\text { Primary } \\
\text { Educational } \\
\text { Center }\end{array}$ \\
\hline Number of Students & 970714 & 2490806 \\
\hline Number of Teachers & 52634 & 140152 \\
\hline Number of Places & 23492 & 28539 \\
\hline Number of Vulnerable Students & 606426 & 1415964 \\
\hline $\begin{array}{l}\text { Number of Schools in Vulnerable } \\
\text { Areas }\end{array}$ & 6208 & 5605 \\
\hline $\begin{array}{l}\text { Number of Teachers in Vulnerable } \\
\text { Schools }\end{array}$ & 24597 & 57595 \\
\hline Number of Non-vulnerable Students & 364288 & 1074842 \\
\hline Number of Schools in Non-vulnerable & 17285 & 22934 \\
\hline $\begin{array}{l}\text { Number of Teachers in Non- } \\
\text { vulnerable schools }\end{array}$ & 28037 & 82557 \\
\hline
\end{tabular}

For the creation of maps, the tool "unite attributes by location" is used, which is a data management tool, of the QGIS software, which generates a Shapefile with all the data, of which in the layer properties, the color is colored map in graduated form in the intervals of 2-20 and from 20 to the maximum value, the maps based on the number of students for each teacher in the levels of kindergarten and primary education are shown.

\section{RESULTS}

In Fig. 2, the reader can see the map generated for the kindergarten level, where in red it can see the districts where there are vulnerable students, since the student-teacher relationship is greater than 20 , reaching at a school with a ratio of 42; this area represents a level of high vulnerability since it is complicated to be able to take care of such a large number of students, and especially minors, such as students in kindergarten education, which is further complicated in emergency situations; the total number of students in this area is 606426, which represents a vulnerable population of $62.47 \%$ of students in kindergarten education. On the map, it can also see the areas where the relationship between students and teachers is not vulnerable since it is within in the norm; and finally, some areas were not taken into account for presenting records considered erroneous, which were explained above.

In Fig. 3, the reader can see the map generated for the primary level in national educational centers, where in red, it can see the districts where there are vulnerable students, since the student-teacher relationship is greater than 20, reaching a maximum of meeting an educational center with a ratio of 46 ; This area represents a high level of vulnerability, and it is further complicated in emergency situations; the total number of students in this area is 1415964, which represents a vulnerable population of $56.85 \%$ of primary school students. On the map, it can also see the areas where the student-teacher relationship does not represent vulnerability since they are within what is specified by the norm; and finally, the areas not taken into account for representing records considered erroneous, which were explained above. 


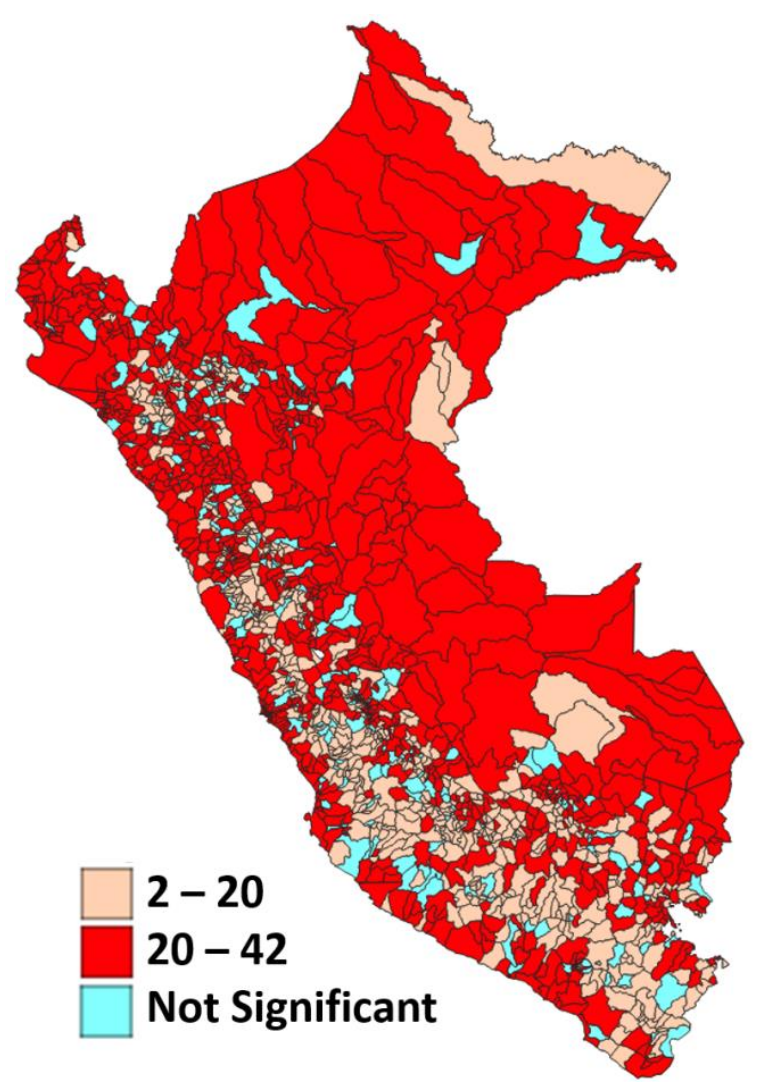

Fig. 2. Map of the Kindergarten Level of National Educational Centers.

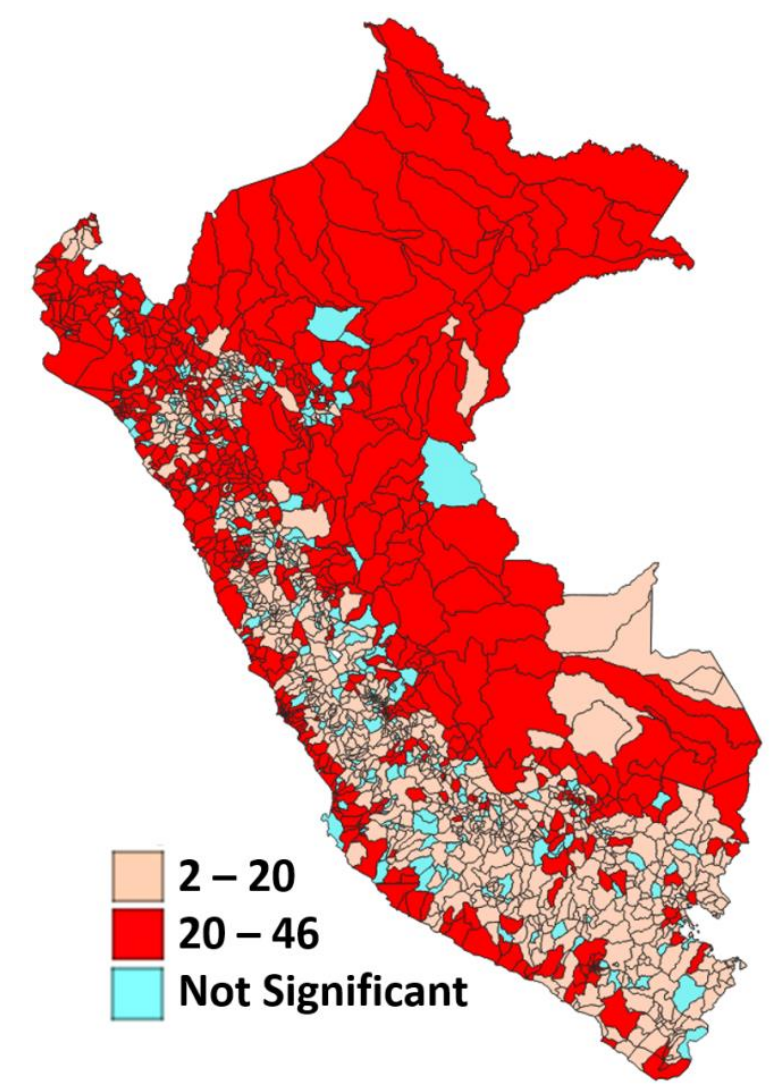

Fig. 3. Map of the Primary Level of National Educational Centers.

\section{DISCUSSION}

According to data from the World Bank and the Statistical Institute of the United Nations Educational, Scientific and Cultural Organization (UNESCO) Fig. 4, updated until 2018 shows that the national average of Peru, in the relationship student - teacher for the level of primary education was approximately 17 [9]; as well as for the year 2019 the national average remains at 17.77 .

For the level of kindergarten education, the data of the World Bank and UNESCO Fig. 5, updated until 2018 shows that the national average of Peru was 19 [10], and by 2019, according to MINEDU data is 18.44 .

In [11] they show that the most vulnerable areas to telluric movements in Peru, are the coastal areas that have a very high vulnerability assessment in addition to the zones corresponding to the zones of the forest and part of the jungle; They mention that areas with high and very high vulnerability reach $27 \%$ of national territory.

The Ministerio del Ambiente del Perú, (MINAM), in [12] shows maps and analysis of the geography of Peru, also it shows coastal areas are in risk to suffer of earthquake disasters, as well as areas of the jungle, to flooding; correlating with the maps shown, which is a high risk for students in the aforementioned areas.

The data in this article is presented in order to report the vulnerability status of the school-age population to some emergency situation. As future work, the use of this information is proposed to build a virtual training mechanism for the teachers.

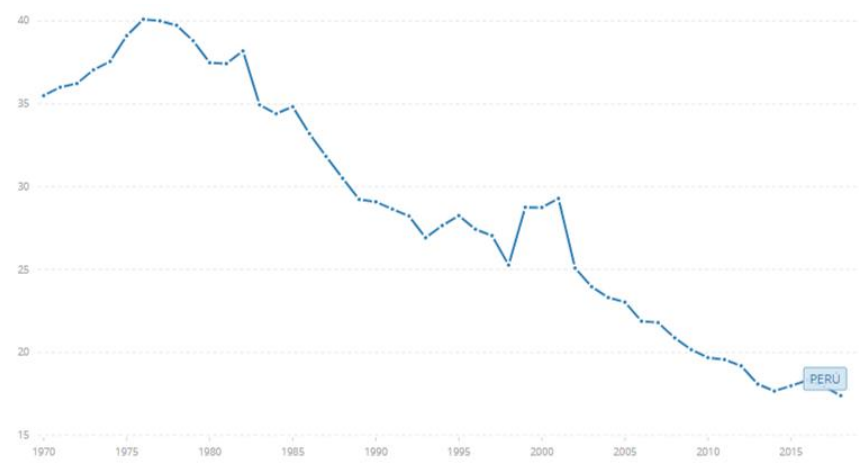

Fig. 4. Student-Teacher Ratio, Primary Level [9].

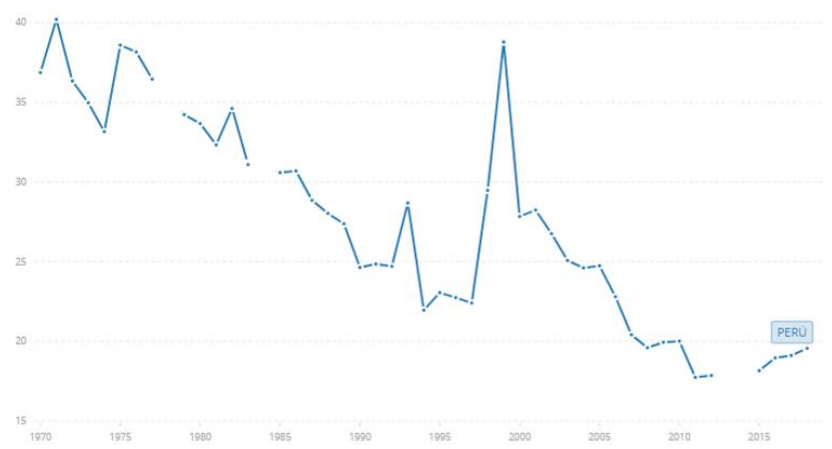

Fig. 5. Student-Teacher Ratio, Kindergarten Level [10]. 


\section{CONCLUSIONS}

The main contribution of this study is to provide information on the current relationship between students and teachers in schools that are administrated by the Peruvian state, and there is no similar research in Peru that uses a Geographic Information System (GIS), which cannot show the most vulnerable areas. This researches are very important, as it allows us to become aware of the vulnerability, to which many children suffer at the national level.

In the current situation, it would be difficult for teachers to take control in emergency situations, so it is important to establish strategies that allow the student-teacher relationship to be reduced in vulnerable areas, adding more prepared teachers to face emergency situations, especially in areas with constant telluric movements, heavy rains, or areas exposed to hazards, due to the geography of the Peruvian territory. This paper gives us a global look at reality, and allows us to call attention to the authorities to prepare and ensure the wellbeing of the students located in the red areas of the maps shown, since they are areas with a high student-teacher relationship; the coastal areas are the most vulnerable since Peru is a seismic country, which is a risk for the educational centers located near the sea; as well as in the jungle areas, since this area represents a greater area of vulnerability.

It is recommended to the relevant authorities, to distribute teachers equitably at the national level, by sending more teachers to high-risk areas, thereby reducing the lack of staff in vulnerable centers; in addition, teachers must be trained frequently and systematically in first aid, so that they can act adequately in an emergency in their educational centers.

\section{REFERENCES}

[1] "Goal 4 - Sustainable Development Knowledge Platform," 2019. [Online]. Available: https://sustainabledevelopment.un.org/sdg4. [Accessed: 06-Aug-2019].

[2] D. Pedder, "Are small classes better? Understanding relationships between class size, classroom processes and pupils' learning," Oxford Rev. Educ., vol. 32, no. 2, pp. 213-234, May 2006.

[3] "Uno de cada cuatro escolares accidentados en colegios sufrió una fractura." [Online]. Available: https://andina.pe/agencia/noticia-unocada-cuatro-escolares-accidentados-colegios-sufrio-una-fractura700396.aspx. [Accessed: 07-Aug-2019].

[4] E. Onís González, I. Varona Pérez, M. Gil Pérez, C. Felici, and P. Embid Pardo, "Lesiones no intencionadas en el centro escolar: ¿de qué estamos hablando?," Pediatría Atención Primaria, vol. 17, no. 68, pp. 333-339, Dec. 2015.

[5] R. Alba Martín and R. Alba Martín, "Educación para la salud en primeros auxilios dirigida al personal docente del ámbito escolar," Enfermería Univ., vol. 12, no. 2, pp. 88-92, Apr. 2015.

[6] MINEDU, "Resolución Ministerial N. ${ }^{\circ}$ 721-2018-MINEDU," 2018. [Online]. Available: http://www.ugel06.gob.pe/portal/images/banners/ 2019/RM_N_721-2018-MINEDU.pdf.

[7] I. Muñoz Tafur, "Conocimiento Sobre Primeros Auxilios En Docentes, Institución Educativa Emblematica 'San Juan De La Libertad'Chachapoyas - 2016."

[8] L. Andrés et al., "LOS Sistemas De Información Geográfica (Sig), Una Gran Herramienta Para La Silvicultura Urbana,” 2006.

[9] "Proporción alumnos-maestro, nivel primario | Data." [Online]. Available: https://datos.bancomundial.org/indicador/SE.PRM.ENRL. TC.ZS end=2018\&locations $=$ PE\&name_desc $=$ false $\&$ start $=1970 \&$ type $=$ points\&view=chart. [Accessed: 07-Aug-2019].

[10] "Relación alumno-maestro, preescolar | Data." [Online]. Available: https://datos.bancomundial.org/indicador/SE.PRE.ENRL.TC.ZS ?locatio ns=PE. [Accessed: 07-Aug-2019].

[11] S. Villacorta, L. Fidel, and Z. Carrion, "Mapa De Susceptibilidad Por Movimientos En Masa Del Perú.," Rev. la Asoc. Geológica Argentina, vol. 69, no. 3, p. 58, 2012.

[12] Ministerio del Ambiente del Perú, "Memoria Descriptiva Del Mapa De Vulnerabilidad Física Del Perú,” 2011. 